\title{
On the mysterious Hylobius huguenini Reitter, 1891 (Coleoptera: Curculionidae: Molytinae)
}

\author{
Christoph GERMANN \\ Naturhistorisches Museum der Burgergemeinde Bern, Bernastrasse 15, CH-3005 Bern \\ and Natur-Museum Luzern, Kasernenplatz 6, CH-6003 Luzern, Switzerland. \\ E-mail: germann.christoph@gmail.com
}

\begin{abstract}
During verifications of museum material for the Catalogue of the Palaearctic Coleoptera, the type specimen of Hylobius huguenini Reitter, 1891 conserved in the Hungarian National Museum was examined. The type specimen had been found by Gustav Huguenin in the Emmental region in Switzerland. The species was never found again and remained therefore mysterious. After the examination of the type specimen, it became clear that Hylobius huguenini belongs to the American genus Heilipodus Kuschel, 1955 (comb. nov.), and there it ranks as a good species next to Heilipodus goeldii sp. nov., described here, and H. polyspilus (Pascoe, 1889), both from Brazil. The type specimens of Heilipodus goeldii sp. nov. were found in the Emil August Göldi-collection in the Natural History Museum of the Burgergemeinde Bern.
\end{abstract}

Keywords. new combination, Heilipodus goeldii, new species, Brazil, Switzerland.

Germann C. 2012. On the mysterious Hylobius huguenini Reitter, 1891 (Coleoptera: Curculionidae: Molytinae). European Journal of Taxonomy 20: 1-8. http://dx.doi.org/10.5852/ejt.2012.20

\section{Introduction}

Hylobius huguenini Reitter, 1891 was described, based on a single female specimen from the Emmental, a region from hilly to mountainous altitudes between the cantons Berne and Lucerne on the northern side of the Swiss Alps. The species was never found again, and therefore its identity remained mysterious. It was included in the Fauna Coleopterorum Helvetica by Stierlin (1898) in the World Catalogue by Dalla Torre \& Schenkling (1932), and as a doubtful record also in the checklist of the Swiss weevils (Germann 2010). It was previously stated that - based on pictures of the type specimen - the specimen is more similar to the American species of the genus (Germann 2011).

During the re-examination of species names for the catalogue of Palaearctic Coleoptera, Miguel AlonsoZarazaga (Madrid, Spain) asked me to unravel this mystery, and as a highly endemic Hylobius restricted to the Emmental-region is very unrealistic, I suspected a misplaced specimen. When Gustav Huguenin, a Swiss internist and pathologist (1840-1920), collected the specimen on which Reitter (1891) based his description, exhaustive plantations of mostly North American conifers were made around the Entlebuch, a subregion of the Emmental. As Huguenin visited Bad Weissenburg in the Simmental several times in the years 1885-1903 (Lätsch 1991), he could have collected the specimen during this time, probably visiting his relatives at Krauchtal, where he was born. So a promising track to solve the mystery, was 
to check for misplaced Holarctic members of the genus Hylobius Germar, 1817. But after comparing specimens of North American Hylobius from NHM and NMNH, previously identified as such based on the key by Warner (1966), with the type specimen of H. huguenini, this track proved to be wrong. The detailed and critical re-examination of the type finally revealed that $H$. huguenini belongs to the genus Heilipodus Kuschel, 1955 (new combination). In comparison with specimens from the Emil August Göldi-collection (NMBE), H. huguenini comb. nov. is closely related to H. goeldii sp. nov. described below, and both species are similar to Heilipodus polyspilus (Pascoe, 1889) from Brazil

\section{Material and methods}

Photographs were taken with a 5-megapixel digital camera (Leica DFC 420), the genitalia were photographed in glycerine. Series of images were captured through a binocular (Leica MZ16) and processed by an Auto-Montage software (Imagic Image Access, Version 8). All measurements were taken digitally with the measurement-tool of the above mentioned Auto-Montage software.

Material was examined from the following collections:

$\mathrm{NHM}=$ The Natural History Museum, London

HNHM $=$ Hungarian Natural History Museum, Budapest

$\mathrm{NMBE}=$ Naturhistorisches Museum der Burgergemeinde Bern

NMBA $=$ Naturhistorisches Museum Basel

$\mathrm{NMNH}=$ Smithsonian Institution National Museum of Natural History, Washington DC

\section{Results}

Class Hexapoda Blainville, 1816

Order Coleoptera Linné, 1758

Superfamily Curculionoidea Latreille, 1802

Family Curculionidae Latreille, 1802

Genus Hylobius Germar, 1817

Genus Heilipodus Kuschel, 1955

Heilipodus huguenini (Reitter, 1891) comb. nov.

Figs 1A, C, E, G; 2G-H, J

Hylobius huguenini Reitter, 1891: 97 (description).

Hylobius huguenini - Stierlin 1898: 298 (faunistic catalogue). — Dalla Torre \& Schenkling 1932: 16 (World Catalogue). — Germann 2010: 112 (faunistic checklist). — Germann 2011: 160 (supplement to faunistic checklist).

\section{Remark}

The type specimen is in a relatively good condition, the tarsal segments 2-5 of the right hind leg are missing as well as the onychium of the left fore leg. The specimen is slightly immature; this explains its light reddish-brown colour.

\section{Holotype}

†, "Schweiz Emmen-Tal [handwritten]" // "Holotypus Hylobius Huguenini Reitter 1891 [label with red margin]" // "Emmenthal" // "Hyl. Huguenini Rtr. Emmenthal Schweiz [handwritten]" // "Coll. Reitter" (HNHM). 


\section{Measurements}

Size $8.6 \mathrm{~mm}$ (without rostrum).

\section{Redescription}

Colour. Body, head, antennae and legs reddish-brown (see above).

VestiTuRE. Body, head and legs covered with elongated, oval, yellowish scales of variable width. Tips of broader scales truncated. Frons covered with broader scales. Scarcely standing scales restricted to first fifth of rostrum. Pronotum with broader scales forming lateral bands at each side just before humeral calli of the elytra. Surrounding scales thinner. Elytra with broader and thinner scales patchily arranged, and forming short bands at base of the $3^{\text {rd }}$ and especially $5^{\text {th }}$ interstriae. Broader scales are denser just behind second half of elytra, forming a diffuse transverse banding. Scutellum very densely covered with overlapping whitish broader scales.

HEAD. (Fig. 1E) Globular, rostrum 3.5 times as long as wide, eyes oval and flat. Interocular distance half as wide as base of rostrum. Rostrum narrowest in its middle, widened to apex to about the size at base.

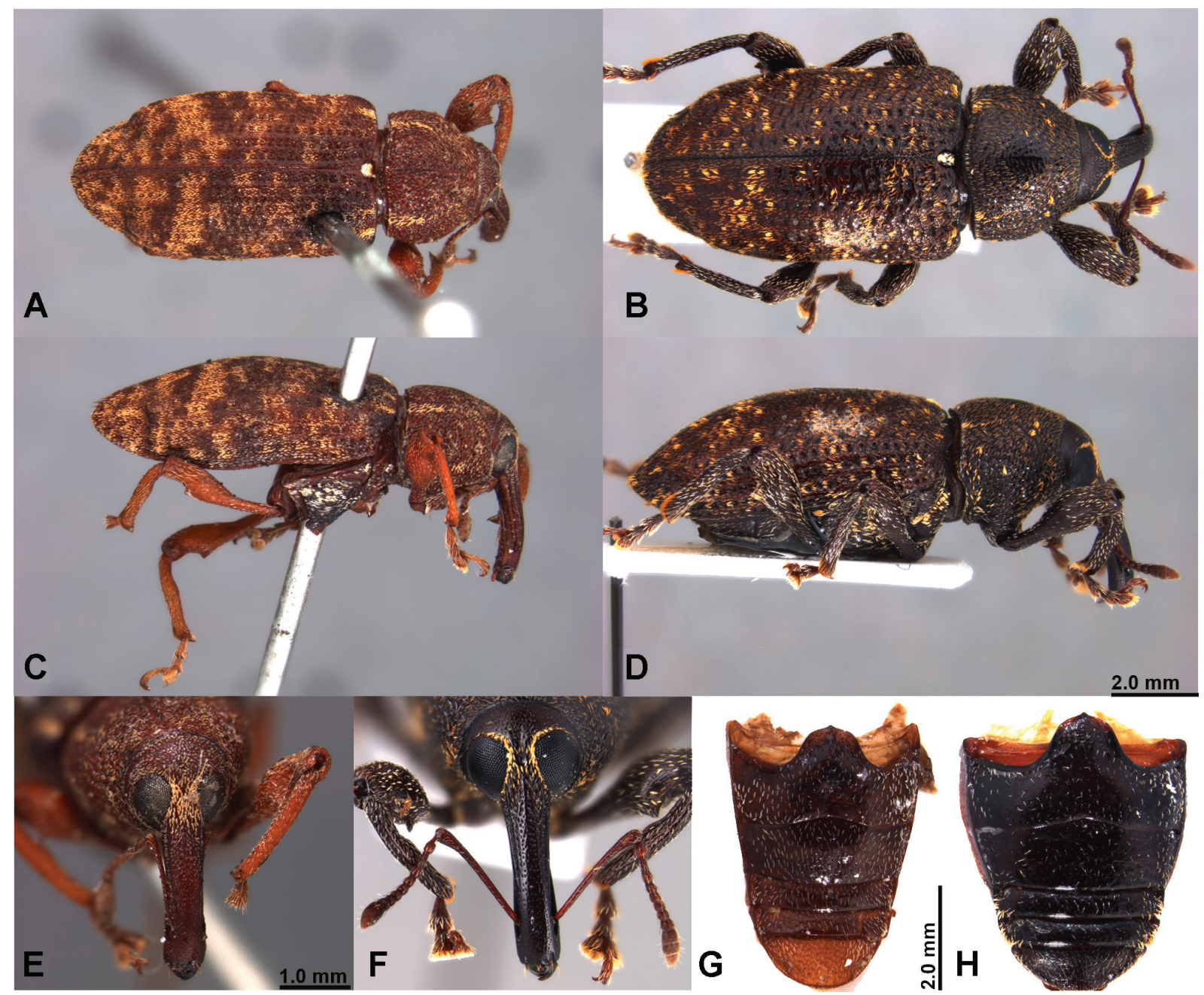

Fig. 1. A, C, E, G. Heilipodus huguenini (Reitter, 1891) comb. nov., holotype. A. Habitus dorsal. C. Habitus lateral. E. Head and rostrum. G. Ventrites. - B, D, F, H. Heilipodus goeldii sp. nov. paratype, ditto. 
Rostrum striate and weakly punctate on its first half; only faintly punctate and glossy towards apex. Antennae inserted after last third of rostrum; scrobes from the anterior margin of the eyes apicalwards. Scrobes visible from above from the middle of the rostrum to the apex. Antennal scape reaching base of rostrum. Funicular segments as follows: $(\mathrm{L} / \mathrm{W}): 1^{\text {st }}: 2.3,2^{\text {nd }}: 2.1,3^{\text {rd }}: 1.2,4^{\text {th }}: 0.9,5^{\text {th }}$ and $6^{\text {th }}: 0.7$ and $7^{7^{\text {th }}}:$ 0.8 , club oblong oval.

Pronotum. (Fig. 1A, C) Transverse ( $\mathrm{L} / \mathrm{W}=0.7$ ), widest just behind the middle, strongly constricted towards fore margin, densely tuberculate and transversely wrinkled, carinate in the middle, tubercles glossy. Slightly curved in lateral view. Base weakly sinuate, bulged towards scutellum.

ElYTRA. (Fig. 1A, C) Elongate ( $/ \mathrm{W}=1.8)$, parallel sided. Base sinuate. Shoulders well pronounced, slightly convex at disc in the middle. Elytra strongly constricted before their last fifth, therefore convex on each side before elytral declivity; apex flattened in lateral view. Striae linear and regularly punctate, interstriae about as wide, convex and glossy. Striae and interstriae weakly blurred by transverse wrinkles.

Legs. Strong, all femora strongly dentate, tibiae sinuate at inner side, apex with long curved uncus at inner angle. Tips of tibiae in-and outside (ventrally and dorsally) with apical combs, bristles light brown; dorsal row of the apical comb of hind tibiae composed of more than two bristles in parallel. Four visible tarsal segments, $1^{\mathrm{s}} \mathrm{t}$ segment 1.5 times longer than $2^{\text {nd }}, 3^{\text {rd }}$ of about the same length, twice as wide, $4^{\text {th }}$ segment tiny, $5^{\text {th }}$ reaching twice as far as $3^{\text {rd }}$. Claws simple.

АвDomen. (Fig. 1G) Five ventrites, process of first ventrite broadly rounded with tuberculiform tip.

Female Genitalia. Ventrite 8 with apodeme as long as plate, distinctly constricted before plate. Plate broad, feebly sclerotized, V-shaped, setose at apex. Spermatheca with very long and straight nodulus, cornu short and very strongly bent towards nodulus (Fig. 2H, J). Ovipositor with broad styli (Fig. 2G).

Heilipodus goeldii sp. nov.

Figs 1B, D, F, H; 2A-C, I, K-L

\section{Etymology}

The new species is dedicated to Emil August Göldi (1859-1917) late director of the Museu Paraense (now Museu Paraense Emilio Goeldi).

\section{Holotype}

§ૈ, “M, H. d. Mathan Obidos 1904/1905 Mus. Goeldi Paráh”, (new) red label: Holotype Heilipodus goeldii sp. nov. Germann des. 2012 (NMBE).

\section{Paratypes}

2 우, same data as holotype, (new) red label: Paratype Heilipodus goeldii sp. nov. Germann des. 2012 (NMBE).

\section{Type locality}

Brazil, Pará, Obidos (Amazon Basin).

\section{Size}

$\delta: 8.5 \mathrm{~mm}$; $q 9$ : 9.3 and $9.5 \mathrm{~mm}$ (without rostrum).

\section{Description}

Colour. Body, head, antennae and legs dark-brown. 


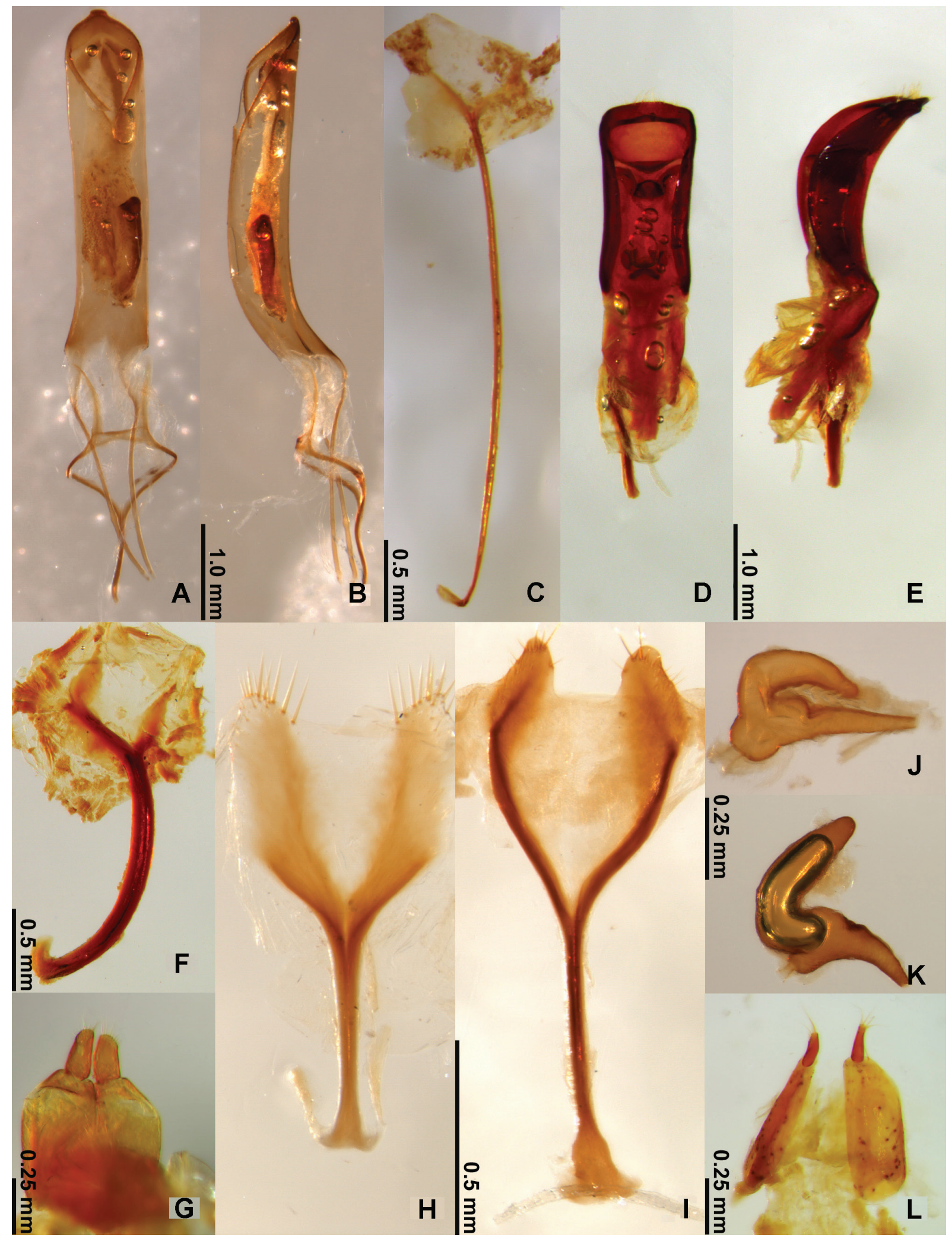

Fig. 2. A-C. Heilipodus goeldii sp. nov., holotype. A. Aedeagus dorsal. B. Ditto ventral. C. Ventrite 8. - D-F. Heilipodus polyspilus (Pascoe, 1889), ditto. — G-H, J. Heilipodus huguenini (Reitter, 1891) comb. nov., holotype. G. Ovipositor. H. Ventrite 8 of female. J. Spermatheca. - I, K-L. Heilipodus goeldii sp. nov., paratype. I. Ventrite of female 8. K. Spermatheca. L. Ovipositor. 
VestituRE. Body, head and legs covered with elongated, oval, yellowish scales of variable width. Tips of broader scales truncated. Eyes encircled with broader scales. Scarcely standing scales restricted to first fifth of rostrum. Pronotum with broader scales forming lateral spots at each side just before humeral calli of the elytra. Surrounding scales thinner. Elytra with broader and thinner scales patchily arranged, and forming spots at base of the $3^{\text {rd }}$ and especially $5^{\text {th }}$ interstriae. Scutellum very densely covered with overlapping whitish broader scales.

Head. (Fig. 1F) Globular, rostrum 3.5 times longer than wide, eyes oval and flat. Interocular distance half as wide as base of rostrum. Rostrum narrowest in or just behind its middle, widened to apex to about the size at base. Rostrum striate and weakly punctate on its first half; only faintly punctate and glossy towards apex. Antennae inserted behind last third of rostrum; scrobes from the anterior margin of the eyes apicalwards. Scrobes visible from above from the middle of the rostrum to the

ApEX. Antennal scape reaching base of rostrum. Funicular segments as follows (L/W; holotype): $1^{\text {st }}: 1.8$, $2^{\text {nd }}: 2.7,3^{\text {rd }}: 1.2,4^{\text {th }}: 1.0,5^{\text {th }}: 1.0,6^{\text {th }}: 1.1$ and $7^{\text {th }}: 0.8$, club oblong oval.

Pronotum. (Fig. 1B, D) Transverse (L/W = 0.6-0.7), widest just behind the middle, strongly constricted towards fore margin, densely tuberculate and transversely wrinkled, weakly carinate in the middle, tubercles glossy. Slightly curved in lateral view. Base sinuate, convex towards scutellum.

Elytra. (Fig. 1B, D) Elongate ( $\mathrm{L} / \mathrm{W}=1.6-1.7)$, widest in first third. Base sinuate. Shoulders well pronounced, slightly convex at disc in the middle. Elytra constricted before their last fifth, therefore convex on each side before elytral decline; apex flattened in lateral view. Striae more or less linear and punctate, interstriae about as wide, convex and glossy. Striae and interstriae blurred by coarse transverse wrinkles.

Legs. Strong, all femora strongly dentate, tibiae sinuate inside, apex with long curved uncus at inner angle. Tips of tibiae in-and outside (ventrally and dorsally) with apical combs, bristles light brown; dorsal row of the apical comb of hind tibiae composed of more than two bristles in parallel. Four visible tarsal segments, $1^{\text {st }}$ segment 1.5 times longer than $2^{\text {nd }}, 3^{\text {rd }}$ of about the same length, twice as wide, $4^{\text {th }}$ segment tiny, $5^{\text {th }}$ reaching twice as far as $3^{\text {rd }}$. Claws simple.

AbDomen. (Fig. 1H) Five ventrites, process of first ventrite broadly rounded with tuberculiform tip.

Female Genitalia. Ventrite 8 with apodeme as long as plate, distinctly constricted before plate. Plate broad, feebly sclerotized, rhomboidal, setose at apex. Spermatheca with long, bent and pointed nodulus, cornu elevated and straight (Fig. 2I, K). Ovipositor with slender styli (Fig. 2L).

Male genitalia. (Fig. 2A-B) median lobe of aedeagus parallel sided, containing a cuneiform sclerite inside. Tip of penis tuberculiform. Ventrite 8 with very long apodeme (Fg. 2C).

\section{Sexual dimorphism}

Weak, last ventrite of the male specimen bulged in the middle, rostrum of the male more coarsely striate.

\section{Differential diagnosis}

Very close to H. huguenini comb. nov., differences are as follows: i) eyes encircled with scales; ii) habitus more robust, elytra broader; iii) scales more spotted, not forming transverse bandings; iv) striae and interstriae more blurred by coarse transverse wrinkles; v) scales forming lateral spots on pronotum instead of bandings; vi) median carina on pronotum less pronounced; vii) ventrites more transverse; viii) female genitalia different (Fig. 2G-L). Both species are similar to Heilipodus polyspilus (Pascoe, 1889) (a single male specimen with the following indications was examined: "Brasilien, Porto Alegre, X.-XII.58 K.E. 
Hüdepohl" coll. Frey, NMBA) in their general habitus, but differ by i) the much less coarsely tuberculate pronotum, by ii) the indistinct third interstriae on the elytra, which are broadened and elevated in $H$. polyspilus, by iii) the light brown bristles of the apical combs of tibiae, and by iv) the male genital organs (Fig. 2D-F), note that the male of H. huguenini comb. nov. is unknown.

\section{Discussion}

The genus Heilipodus was established by Kuschel (1955) to accommodate part of the species formerly belonging to Heilipus Germar, 1824. The genus Heilipodus Kuschel, 1955 is distributed, according to Wibmer \& O'Brien (1986), in South America with 87 species (including the present ones transferred and described), while 36 species are known from Central America (O’Brien \& Wibmer 1982). No species are known from North America.

Concerning their lifestyle, as far as it is known, Heilipodus are stem borers of various plants. Larvae and pupae of H. erythropus (Klug, 1829) were collected by Rosado-Neto (1980) in Brazil (Paraná) from Eryngium L. (Apiaceae). Another species - Heilipodus intricatus (Boheman, 1836) - was used in Australia as potential biological control organism against the invasive Baccharis halimifolia L. (Asteraceae) from the USA (Riding 1983).

Heilipodus is characterised by the following traits after Kuschel's key (1955):

1. frons between the eyes narrower than rostrum at its base (characteristic of the subtribe Hylobiina);

2. dorsal comb of the hind tibiae consisting of more than one row of bristles;

3. epistome not prolonged in the middle;

4. femora strongly teethed;

5. hind margin of first ventrite cut;

6. scrobes directing towards lower side of rostrum;

7. prementum glabrous;

8. basal fold of first ventrite simple (not dilated);

9. ovipositor: coxite with stylus;

10. antennal scape not reaching the eyes;

11. frons much narrower than rostrum at base, fore tibiae not sulcate at dorsal side.

Based on these characters, H. huguenini belongs to the genus Heilipodus (comb. nov.) and with its spotty pattern it is similar to $H$. goeldii sp. nov. and to $H$. polyspilus. All three species belong to the more discretely coloured species of the genus. After the author's investigations H. huguenini comb. nov. is a valid species within the genus Heilipodus. The original areal is most likely somewhere in South America, and based on its similarity to $H$. goeldii sp. nov., probably in the Amazon Basin. However, it remains mysterious as to how a specimen of this presumably Neotropical species found its way to the Emmental region in Switzerland. International trading is known around Burgdorf, which could have raised the chance of introduced specimens travelling along with goods. Also a mislabelled specimen or an accidentally misplaced specimen during exchange of material by Huguenin (or Reitter) with colleagues cannot be excluded. However, the starting hypothesis that the specimen was introduced together with pine trees from North America can be rejected.

\section{Acknowledgements}

I am thankful to Miguel Alonso-Zarazaga (Madrid) for highlighting the persisting difficulties of the status of Hylobius huguenini. Otto Merkl (HNHM) kindly enabled me to examine the type specimen, and Zoltan György (HNHM) prepared helpful photographs for a pre-examination. Thanks to David Furth and Alexander Konstantinov (NMNH), Eva Sprecher (NMBA), and to Max Barclay (BMNH) for the loan of specimens for comparison. Thanks to Peter Nagel (Department of Environmental Sciences, 
Institute of Biogeography, University of Basel) and Michael Geiser (NMBA) for transmitting the type specimen. I am thankful to two anonymous referees for their valuable comments on the manuscript.

\section{References}

Dalla Torre K.W. von \& Schenkling S. 1932. Curculionidae: Hylobiinae. Coleopterorum Catalogus 28 (122), W. Junk, Berlin.

Germann C. 2010. Die Rüsselkäfer der Schweiz - Checkliste (Coleoptera, Curculionoidea) mit Verbreitungsangaben nach biogeografischen Regionen. Mitteilungen der Schweizerischen Entomologischen Gesellschaft 83: 41-118.

Germann C. 2011. Supplement zur Checkliste der Rüsselkäfer der Schweiz (Coleoptera, Curculionoidea). Mitteilungen der Schweizerischen Entomologischen Gesellschaft 84: 155-169.

Kuschel G. 1955. Nuevas sinonimias y anotaciones sobre Curculionoidea (Coleoptera). Revista Chilena de Entomologia 4: 261-312.

Lätsch H. 1991. Der Internist Gustav Huguenin (1840-1920). Juris Druck \& Verlag, Zürich.

O’Brien C.W. \& Wibmer G.J. 1982. Annotated checklist of the weevils (Curculionidae sensu lato) of North America, Central America and the West Indies. Memoirs of the American Entomological Institute 34: 1-382.

Reitter E. 1891. Uebersicht der europäischen Arten der Coleopteren-Gattung Hylobius Schönherr. Wiener Entomologische Zeitung 10 (3): 97-98.

Riding N. 1983. Groundselmania. Entomological Society of Queensland News Bulletin 10 (10): 125128.

Rosado-Neto G. H. 1980. Description of larva and pupa of Heilipodus erythropus (Klug, 1829) (Coleoptera, Curculionidae). Revista Brasileira de Entomologia 24 (2): 111-115.

Stierlin G. 1898. Fauna Coleopterorum Helvetica. Teil II. Bolli und Boecherer, Schaffhausen. http:// dx.doi.org/10.5962/bhl.title.8772

Warner R.E. 1966. A Review of the Hylobius of North America, with a New Species Injurious to Slash Pine (Coleoptera: Curculionidae). The Coleopterists Bulletin 20 (3): 65-81.

Wibmer G.J. \& O'Brien C.W. 1986. Annotated checklist of the weevils (Curculionidae sensu lato) of South America. Memoirs of the American Entomological Institute 39: 1-563.

Manuscript received: 2 May 2012

Manuscript accepted: 4 August 2012

Published on: 8 August 2012

Topic editor: Koen Martens

In compliance with the $I C Z N$, printed versions of all papers are deposited in the libraries of the institutes that are members of the EJT consortium: Muséum National d'Histoire Naturelle, Paris, France; National Botanic Garden of Belgium, Meise, Belgium; Royal Museum for Central Africa, Tervuren, Belgium; Natural History Museum, London, United Kingdom; Royal Belgian Institute of Natural Sciences, Brussels, Belgium; Natural History Museum of Denmark, Copenhagen, Denmark. 